\title{
Text Recitation in Foreign Language Learning: Its Effectiveness on the Learning of Multi-word Expressions
}

\author{
Takeshi Matsuzaki \\ Meiji University
}

This paper reports on a small-scale study that explored the extent to which two types of recitation tasks that engaged foreign language learners in memorization of conversational turns prepared in advance would differentially lead to the learning of multi-word expressions. Three groups of Japanese college learners of English participated in this research: a whole-text recitation group, a partial-text recitation group, and a contrast group. Results of the speaking tests administered suggest that whole- and partialtext recitation approaches are both conducive to the learning of language chunks and that there is considerable variance in facilitative effects between the two.

\section{INTRODUCTION}

While formulaic language abounds in language use (e.g., Erman \& Warren, 2000), formulaicity remains an area where L2 learners only very slowly approximate to or will never reach the proficiency of native speakers (Pawley \& Syder,1983), and yet deviant use of multi-word expressions by L2 learners can be associated with an increased and sustained processing burden by native speakers (Millar, 2010; Stengers et al., 2011). With adult L2 learners in a foreign language context, one reason for this learning difficulty is that those learners do not sufficiently experience 'pattern-based learning' (Ellis, 1996, 2002), by which we acquire readily accessible chunks of language. Even if ample opportunities for such learning are available, adult learners are already equipped with a broad range of what Anderson and Lynch (1988) call 'schematic' and 'contextual' knowledge, which according to Skehan (1988), aids comprehension and production but can significantly hamper learning of linguistic items, including pattern-based learning. Still another huge challenge for adult learners is that they are, unlike child language learners, not protected by the socio-interactional 'bubble' (Wray \& Perkins, 2000), which would otherwise reduce socio-interactional pressures in realtime communication and increase the chance of attention being paid to linguistic analysis. To facilitate learning by these learners, then, a number of studies investigating the effectiveness of different ways to teach multi-word strings have been conducted. Text memorization figured in these studies as one instructional strategy, and it is the focus of the study reported on in this paper.

\section{LITERATURE REVIEW}

SLA literature to date does not offer much analysis of text memorization, and there is an undeniable scarcity of studies on the effects of text memorization (Boers \& Lindstromberg, 2012; Dai \& Ding, 2010). 
Among the scarce studies that have been conducted, four relatively recent and noteworthy investigations into such effects are reviewed here. The first two studies reviewed here are qualitative, whereas the others are quantitative. Taken as a whole they indicate that text memorization is conducive to the learning of multi-word strings, and the particularities of each study have also spawned various ideas for future research on teaching L2 phrases.

Wray (2004) examined the performance of an adult learner taking part in the British television program "Welsh in a Week." A novice learner of Welsh studied a considerable number of formulaic phrases in order to become sufficiently fluent with a limited amount of Welsh for meeting the challenge of a public presentation. After four days of instruction, the learner successfully performed a cooking demonstration in her L2. The findings of Wray's study suggest that verbatim memorization of lengthy stretches of text may support the oral performance of learners, or at least that of lower-level learners (given that the learner in her study was a beginner). Wray also found, however, that although the learner knew that she would be most successful if she simply memorized the material given to her, five months after her performance she was committing typical learner errors in what she remembered of the original text. One implication of the study is, thus, that adult learners are inclined to process linguistic material through their distinctive analytic filter, and therefore the teaching of formulaic material to them may be a tremendous challenge. While this study clearly shows that having a learner memorize a long text can increase the quality of speech production, it is not clear whether a learner can keep engaging in such a mentally challenging task with different texts for a much longer duration of time, such as an academic semester, and still display high-quality performance. Nor is it clear whether bits and pieces of word strings in the memorized text can be subsequently retrieved during rather impromptu speech production tasks.

Wray and Fitzpatrick (2008, 2010; Fitzpatrick \& Wray, 2006) published a study in which adult ESL learners were required to memorize native-like conversational turns for future interactions. Their study devised discrete cycles of preparation, practice, and conversations with native speakers. First, the participants each worked with a native speaker of English to identify conversations or transactions, related to their own real-life needs that they would have in the near future with native speakers. Next, the participants explained to the native speaker what they would expect to say during the targeted encounters, and together they prepared sets of appropriate native-like utterances. The learners then learned these models by heart through rehearsal, after which they engaged in the targeted authentic conversations with native speakers. The findings of Wray and Fitzpatrick' study suggest that even entirely fixed phrases can be highly beneficial in conversation, while unfamiliar circumstances, as in where unexpected turns show up in the conversation, also reveal tenacious weaknesses that are intrinsic to a predominant reliance on formulaic material. Wray and Fitzpatrick also found that not all participants regarded this model of utterance storage and retrieval as useful, thus indicating the existence of individual differences in preferred learning strategies (see also Fitzpatrick \& Wray, 2006; Wray \& Fitzpatrick, 2008). Their study invites the question of the extent to which memorization of texts that are prepared prior to instruction can promote learning of the phrasal constructions therein.

$\mathrm{Yu}(2009)$ conducted an experimental study investigating whether two different means of learning the word sequence despite the fact (that) result in differential outcomes of the learning of the syntactic rules embedded in the word string, which according to $\mathrm{Yu}$, are problematic for Chinese learners of English, owing to L1 transfer. While the contrast group of the study was given direct instruction on the grammatical aspect of the word string despite the fact (that), the treatment group was instructed to commit to memory the word string through recitation without being given any explicit information about the rules. It was found that the recitation group significantly outperformed the grammar instruction group in the L1-to-L2 translation test. Yu claims that the result lends support to the facilitative roles that rote memorization can play in fostering the learning of multi-word strings. One unique quality of Yu's study is that not only were the students in the recitation group directed to memorize the target item, but they also passed the recitation test given to them before the post-test. This suggests that the better result from the treatment group in Yu's study may have been because the students in that group were tasked with actually reciting the text and not simply instructed to memorize it. In-class recitation activities, therefore, seem to 
have the potential to promote the learning of phrasal constructions. One question and two cautions are in order, however. First, Yu's study focused only on despite the fact (that), so what would have happened if multiple — or even a large number of - phrases had been targeted? Will the same result as Yu's be observed if many items are taught simultaneously or over the course of, say, one academic semester? Second, the translation test used in Yu's study was in a written format. Would those students in the treatment group have been able to outperform the contrast group if there had been a speaking test? Last, although despite the fact (that) was the sole target item, the translation test gave the students 'despite' as part of the prompt. Thus, the results should be interpreted with caution.

Dai and Ding (2010) engaged one group of EFL students in text memorization involving verbatim recitation, during daily independent study time in the course of a school term. Another group, in contrast, was given discretion as to how to use their allotted study time to work with the English texts. In the writing assignments at the end of the term, the text memorization group was found to use more varied and more accurate multi-word expressions than the other group. The findings of Dai and Ding's study suggest that text memorization can be an effective second language learning strategy. The contrasting performance of the two groups at least shows that this strategy is more cost-effective than other strategies tried out by the non-memorization group, because the total amount of time spent by learners in learning on their own was controlled so as to be equal. Another major finding from the Dai and Ding study, revealed by a comparison of high and low achievers, is that low achievers overall benefited more from the text memorization than high achievers, indicating that the method produces more positive effects on formulaic learning when targeting lower-level learners. Their findings on the whole suggest that teachers should be encouraged to employ such practice and engage students in imitating and memorizing the collocations and constructions in the input in order to improve the quality of their output. One limitation of their study, however, is that they measured the participants' improvement only through writing, and without the pressure of strict time constraints. There are thus two cautions in interpreting their findings. First, since the measurement was done through composition writing, the students were free from sociointeractional pressure (Wray \& Perkins, 2000), and as such, they might have been able to attend to the formal aspect of their production more than would have been possible in speaking. Second, because they were given 40 minutes to compose their writing, the students were also not under the same level of timed pressure as normal oral communication would impose.

\section{RESEARCH QUESTION}

Among other limitations, there are three perspectives that are lacking in the relevant empirical studies conducted to date. First, little is known regarding the extent to which, over an extended period of time, memorization can occur by directing learners to memorize a large volume of pre-prepared language material containing multi-word expressions. Certainly, what is memorized in such a manner may neither be readily serviceable in realtime language use nor get entrenched in the long-term memory unless reinforced by repeated encounters. The point here, however, is that there is a first time for anything to be committed consciously to memory, and thus, how much language a group of students can be motivated to memorize by a particular instruction is indeed an important issue for teaching, even if some, or most, of what is memorized evaporates from memory. Second, as far as L2 text memorization studies are concerned, no study to date has tested the differential effects of having learners engage in memorizing the same set of material with different cognitive loads. Can it be said, for example, that engaging learners in memorizing only selected parts of a text results in the same level of learning as engaging them in memorizing the entire text? If lowered cognitive processes can bring about similar or even better outcomes, then they are more time-efficient. Lastly, rather surprisingly, few researchers have used measures of time-constrained speech production that would allow them to directly investigate the ability of their subjects to readily use the target phrases that they had studied within specific instructional frameworks.

With the need for research into these areas in mind, the present study adopted time-constrained speaking tests as measurement tools and investigated the effects of engaging EFL university students, 
over an extended period of time, in two different memorization tasks with the aim of learning the useful phrases contained in a large volume of dialogs prepared prior to instruction. The research question was thus set as follows.

Does engaging foreign language classroom learners, over the course of a semester, in 'whole text' and 'partial text' recitation of a large volume of useful dialogs, prepared in advance of instruction, facilitate the use of the constructions therein in speech production, and is there a significant difference between the two in terms of their facilitative effect?

\section{METHOD}

\section{Participants}

Three groups of political science and economics majors in a private university in Japan participated in this study. Two of the three groups were treatment groups, with the third acting as a contrast group. One of the treatment groups, designated the 'Whole-Text Recitation' Group (WTRG), consisted of 12 students who were in a one-semester study-abroad preparation course taught by the researcher. The other treatment group, the Partial-Text Recitation' Group (PTRG), consisted of another 12 students who were in the same course taught in a different year. WTRG and PTRG followed the same course syllabus. As will be described in detail below, while the participants in WTRG were encouraged to memorize all of the dialogs that were specially prepared for this study, those in PTRG were only required to commit to memory particular parts of those dialogs that contained the constructions of the focus of this study. The last group, the Contrast Group (CG), was comprised of 11 students who were in either one of another two onesemester English classes taught by the researcher. The contents and target populations of these two classes differed: one was a TOEFL iBT preparation class, and the other an oral communication-oriented class. Thus, a total of 35 university students participated in this study.

\section{Dialog Materials}

The researcher developed 66 model English dialogs (3,182 words in total) that would be the language material worked on by the participants in WTRG and PTRG. Making use of his own overseas study experience, and with the help of two native speakers, the researcher created these dialogs so as to be relevant and useful to students in a variety of communicative situations that they themselves may encounter when studying abroad. Attempts were thus made to design the content to be motivating enough for students in WTRG and PTRG, who were all either planning to study or considering studying abroad in the near future.

The dialogs prepared can be roughly categorized in terms of the following three sets of scenes. The first set contained particular scenes that students will experience when traveling abroad: e.g., going through immigration at the airport, making complaints about a hotel room at the front desk, making orders at a restaurant or fast food shop, asking for directions to the nearby post office, asking for a discount in shopping. The second set was about possible exchanges between a student and a university professor: asking a question in class, asking for an extension of submitting an essay, thanking the professor for writing a recommendation letter, and so forth. The last set included a variety of potential campus conversations: meeting for the first time, talking about family, asking for help, asking for advice, talking about last weekend, talking about plans during a long vacation, an invitation to an evening gathering, bumping into each other near the campus, gossiping about a classmate, saying good-bye when finishing school, and so on. The scripts, along with their Japanese translations, were packaged in a booklet, a copy of which was given to each participant in WTRG and PTRG.

\section{Instructional Interventions}

Whole-Text Recitation Group

At the beginning of the semester, the students were informed that the recitation of all the dialogs would account for $30 \%$ of their final grade. During each class, linguistic (e.g., syntactic, phonological, 
pragmatic) explanations relating to a number of these dialogs (roughly 6 on average) were given by the researcher. Every week, for a third or more of the 90-minute class time, students reviewed selected dialogs in pairs and when ready acted them out, also in pairs, to another student or the researcher, with the booklet closed. For each dialog that was successfully performed (i.e., without too much hesitation or many mistakes), the "Checker" signed on the "Check Sheet" for each reciter. When the researcher was the Checker, he also provided brief corrective feedback to the students being checked. When the students were working on the Check, they were encouraged to recite each dialog twice, aiming if possible to do this at one-week intervals. Thus, for each dialog, there was a 1st Check and a 2 nd Check. While the students were working on a Check, the researcher was walking around the classroom, occasionally giving brief corrective feedback to individual students or to the entire class as well. At the end of the semester, the researcher provided each student with an evaluation for the dialog recitation referring to their Check Sheet.

\section{Partial-Text Recitation Group}

As with WTRG, the students in PTRG were informed at the beginning of the semester that $30 \%$ of their final grade would be based on performance of all the dialogs. However, the PTRG participants were only required to memorize the blanks in the dialog booklet (1,047 words in total, 33\% of the entire text). During each class, also similar to WTRG, linguistic explanations on approximately 6 dialogs were given by the researcher. Every week, for a third or more of the class time, students reviewed selected dialogs in pairs, and when ready, read these aloud to each other, to another student, or to the researcher, while looking at the textbook with the Japanese translation covered. The manner in which PTRG performed the dialogs was therefore very different from the manner in which WTRG did them. For each dialog successfully read aloud, the Checker signed on the Check Sheet for each reader. Again, when the researcher was the Checker, he also provided brief corrective feedback to the student being checked. As in the case with WTRG, the students in PTRG were also encouraged to do the 1st Check and the 2nd Check for all dialogs. In all other respects the instruction and evaluation were conducted in exactly the same way as with the WTRG.

The key instructional differences between WTRG and PTRG were thus twofold. First, the materials in which the two groups engaged were the same in terms of content but different in surface form. That is, the dialogs worked on by PTRG had a significant number of blanks, and unlike the students in WTRG, who were required to commit to memory the entirety of each dialog, the students in PTRG were only expected to memorize the words (the phrases which were the study's focus) in those blanks. The second difference was a consequence of having PTRG students work on the material with a multitude of blanks. That is, unlike WTRG's case, where students acted out the dialogs with a partner, participants in PTRG were, when performing the dialogs, directed to do so alone. This direction was given primarily because acting out with a partner would have involved each person reciting fewer phrases, thereby making the task insufficiently challenging.

\section{Contrast Group}

In terms of the focus of this study, the two classes comprising the CG (a TOEFL iBT test preparation course and a communication-oriented English course) had two features in common. First, since they were meant to be the CG collectively, they did not deal with the dialog materials for WTRG and PTRG. Another characteristic they shared-and one that they also shared with the WTRG and PTRG-was that there was in fact extensive memorization involved. The CG students in the TOEFL iBT class were given the assignment of memorizing a large volume of sample responses to the speaking and writing sections of the test. The CG students in the communication-oriented class, conversely, were assigned to pick out a scene from a movie or TV drama of their choice and recite the scene to a partner every week. One rather important difference between the CG and the treatment groups was that even though all classes were elective courses, the final grades for the treatment groups were not counted as part of the students' GPA, a factor that could potentially affect the results. 


\section{Speaking Tests}

All participants took two speaking tests, the first one (the Pre-Test) at the beginning of the semester and the other (the Post-Test) at the end, 14 weeks after the administration of the pre-test. The speaking tests actually consisted of four distinct parts respectively, addressing multiple research questions; however, because the research question addressed in this paper concerns only two of those parts, only the two relevant parts are discussed below. During both tests, each participant sat at a computer and gave their spoken responses to the prompts as they appeared one by one on the screen, speaking into a microphone. Prior to the present study, draft items for the tests to measure use of phrases in speech production had been piloted on 31 Japanese university students attending the previous year's studyabroad preparation course, also taught by the researcher. These students were comparable to the eventual participants in the treatment groups of the main study, because those in the treatment groups were given the finalized speaking tests while taking the same course. Even though the instruments were overall found to be informative and to have acceptable test characteristics, some minor issues were spotted when the researcher was observing the pilot students taking the tests and when he was analyzing the data. Thus, the parts involving those issues were revised. Detailed descriptions of the parts of the speaking tests covered in this report are as follows.

\section{Reading-Aloud Short Sentences}

The first part of both speaking tests was designed to measure the improvement in the participants' ability to properly articulate multi-word strings, sentences of different semantic structures (e.g., a tag question, a question beginning with a WH-word), and words from the dialog textbook. The words selected from the textbook were those commonly identified as troublesome for Japanese learners of English. Although pronunciation was in itself not a primary focus of this study, this read-aloud task was given on the grounds that formulaic language is a multifaceted phenomenon involving a variety of linguistic features that obviously include aspects of pronunciation. Another note about this part of the tests, which was much less cognitively demanding than the remainder of the test, is that giving this component at the beginning was intended to tease out the tension in those participants who might feel intimidated by having other test-takers hear their possibly erroneous responses.

The procedure and characteristic features of this part of the test (both in Pre-Test and Post-Test) are as follows. During each test, the participants were instructed to read aloud 10 short English sentences, each consisting of one specific pronunciation feature. Each prompt started with a Japanese sentence, which was followed by an English translation of the prompt. Some prompts also included particular instruction for reading aloud the English. It should be noted that although the wording for each specific prompt in the Pre-Test was deliberately changed when it appeared in the Post-Test, the prompts in Pre-Test and those in Post-Test were designed to measure the same pronunciation features. This modification was made in order to circumvent aid from any memory traces from the Pre-Test, even though such traces were presumably unlikely, given the long interval between the Pre-Test and the Post-Test (i.e., 14 weeks). An additional note about the wording of the prompts is that English sentences to be read aloud in the Pre-Test were taken directly from the dialog textbook, because the participants had yet to work on the English sentences used in the Pre-Test before taking that test; thus, there was no need to word the prompts differently from the dialog textbook. As for the duration of this part of the test, the participants were given either 10 or 15 seconds per prompt, depending on the overall density of a prompt, to comprehend the prompt and read aloud the English sentence.

For the scoring of a response, either 0 or 1 ( 0 as 'fail' and 1 as 'pass') was given in accordance with the particular pronunciation feature in focus. The full score in this part was thus 10 . Unlike the case of the other part of the speaking tests discussed in this report, detailed below, each participant's total score for this read-aloud task was not standardized into a z-score, even though the prompts in the Post-Test were different from those in the Pre-Test. This was because, as specified above, both sets of prompts primarily addressed the same pronunciation features, and therefore the raw scores for the two tests were judged to be directly comparable. Scoring was done by the researcher three times, with at least a two-week interval between scoring sessions, and for each item a majority score was adopted. A Kruskal-Wallis test was then 
run on the three groups' Pre-Test scores, which confirmed that no significant difference existed among the groups on this part of the test at the onset of the study $(H(2)=2.660, p=.264)$.

Illustrated below is an example of the prompts and notes covering the descriptions laid out above. A summary of all prompts and notes are available in Appendix A.

Pre-Test: You seem to have had a good weekend.

(よい週末を過ごされたようですね)

Post-Test: You seem to have had a bad holiday.

(よくない祝日を過ごされたようですね)

Instruction: Pronounce "to have" colloquially.

Time given: 15 seconds

Scoring point: contraction of "to have"

Original script: You seem to have had a good weekend. (Dialog 16)

\section{Responding Readily}

This part of the speaking tests was designed to see if the participants in WTRG and PTRG made significant improvement compared to the CG participants in making use of the phrases in the dialog textbook in a time-constrained manner over the course of one-semester instruction. Given the limited testing time, only a select few phrases were targeted in this part, although the dialog material contained a plethora of multi-word expressions. Participants were therefore given 16 prompts in Japanese in this segment (both Pre-Test and Post-Test). Their task was to respond to those prompts in English from the computer as if they were speaking to someone. Each prompt required them to either translate part of the Japanese prompt into English or produce something in English that would be a reasonable reaction to the particular situational cues given. Each prompt was meant to tap into the participants' knowledge of the dialogs - or more specifically of the constructions therein - that they worked on in the class, and was also designed in such a way that they would be easily able to respond to it appropriately if they used some particular constructions from the dialog textbook. Moreover, not only did this part attempt to measure memory trace of those phrases in the participants' long-term memory, it also served as a means to assess accessibility, in the sense of access speed, to those sequences stored in memory because the time given to understand and respond to each prompt was only 18 seconds.

As for the contents of the prompts, half of all 16 prompts in each test were designated 'direct application' prompts and the remaining 8 prompts were to serve as 'modified application' prompts. Each direct application prompt was constructed in such a way that a simple re-use of some phrases from the dialog textbook would suffice as an appropriate response. In contrast, successful completion of the remaining prompts, modified application prompts, would not be accomplished by such plain re-use. Rather, if participants wanted to successfully respond to these prompts using some phrases from the textbook, they would have to modify those to fit in the cued situation.

The score for each response was the number of the constructions available in the dialog textbook that were used in the response. There are two things to note regarding the scoring for this part of the test, however. First, accurate use of a phrase was not evaluated in a strict manner. This decision was made because accurate and also fluent speech production was probably beyond the capability of the participants in this study. This was a deliberate choice, and the reason for it is that this study's principal concerns were memory trace and accessibility. This is a theoretically-founded choice, as there is a purported tension between fluency in the sense of fast and smooth production and accuracy, especially under timeconstrained circumstances (Skehan, 1998). Second, each participant's total score for this part of the test was actually standardized into a z-score, which was not done in the case of the read-aloud task. The reason for this decision has to do with the fact that half of the direct and modified application prompts in the Pre-Test respectively (i.e., 4 x $2=8$ items) were replaced, in the Post-Test, with another set of direct and modified application prompts that were meant to tap into the participants' knowledge of constructions that were different from those phrases that the Pre-Test attempted to elicit from the students. That is, the 
raw scores for the 'non-repeated' prompts in this part of the tests would not be statistically comparable, and each student's overall score for this part of the test thus needed to be standardized so that proper score comparisons would be possible. Lastly, counting of the constructions used was done by the researcher three times, with at least a two-week interval between scoring sessions, and for each item a majority score was adopted. Unlike the read-aloud task, this part required transcribing, which was first outsourced to a transcribing company and then all transcribed data was carefully reviewed by the researcher. No significant distinction among the three groups at the onset of the study was found on the direct application prompts $(H(2)=2.073, p=.355)$ or on the modified application prompts $(H(2)=.866, p=.648)$.

An example of the prompts in this part together with the scoring criteria is provided below. All prompts and scoring criteria are summarized in Appendix B.

Target sentence(s): Uh, what do you think of Japan becoming the third world, uh, third biggest world economy after China? (Dialog 7)

Sample modified expression: What do you think of China becoming the second biggest world economy after the US?

Constructions counted: 1) What do you think; 2) think of; 3) Prep. + Noun + Gerund; 4) second + Superlative; 5) after...

\section{Reliability of the Quantitative Measures}

The reliability estimates for the speaking test components reveal one of the limitations of this study. Although it sought to investigate the effectiveness of dialog text memorization as a way to develop one's formulaic language knowledge in a general sense, the text from which to derive test measures was restricted to the dialog material developed for the study-abroad preparation course, which, among other things, prevented the reliability of the test items from being statistically substantiated. As can be seen in Table 1, the estimates are overall not sufficiently high overall. The results and discussion below, thus, have to be interpreted with this limitation in mind.

TABLE 1

RELIABILITY ESTIMATES FOR THE SPEAKING TEST COMPONENTS (CRONBACK ALPHA)

\begin{tabular}{lll}
\hline & Pre-Test & Post-Test \\
\hline Reading-aloud short sentences & .464 & .581 \\
Responding readily & .492 & .729 \\
\hline
\end{tabular}

\section{RESULTS AND DISCUSSION}

Table 2 and Figures 1-2 illustrate the z-score changes for phrases from the dialog material used by the three groups for the 'direct application' prompts, which indicate some instructional effects of both recitation approaches. The Wilcoxon tests run on the performance results of those groups that measured their score changes detected statistically significant changes for PTRG $\left(z=2.197, p=.028^{*}, r=.45\right.$ [medium effect]) and CG $\left(z=-2.580, p=.010^{*}, r=-.55\right.$ [large effect]). Although no significant improvement was found for WTRG $(z=1.099, p=.272, r=.23$ [small effect]), an execution of multiple comparisons of the score changes from Pre-Test to Post-Test seemed in order as a way to see if a significant difference can be found between CG and WTRG, in addition to the obvious disparity between CG and PTRG, as CG's z-score change was a decrease rather than an increase. In fact, the comparisons did reveal that besides the clear difference between CG and PTRG $\left(z=3.078, p=.006^{* *}, r=.64\right.$ [large effect]), there was such a difference between CG and WTRG $\left(z=2.941, p=.010^{*}, r=.61\right.$ [large effect]), while there was, as expected, no significant difference found between WTRG and PTRG $(z=-.140, p=$ $1.000, r=-.03$ [almost no effect]). 


\section{TABLE 2}

IMPROVEMENT IN Z-SCORE FOR CONSTRUCTIONS USED FROM DIALOGS FOR 'DIRECT APPLICATION' PROMPTS

\begin{tabular}{lcccccc}
\hline \multirow{2}{*}{ Group } & \multicolumn{2}{c}{ Pre-test } & \multicolumn{2}{c}{ Post-test } & \multirow{2}{*}{$p$} & \multirow{2}{*}{$r$} \\
\cline { 2 - 5 } & $M$ & $(S D)$ & $M$ & $(S D)$ & & \\
\hline WTRG & -.07 & $(1.89)$ & .60 & $(2.11)$ & .272 & small $(.23)$ \\
PTRG & -.53 & $(1.03)$ & .33 & $(1.34)$ & $.028^{*}$ & medium (.45) \\
CG & .65 & $(2.12)$ & -1.02 & $(1.19)$ & $.010^{*}$ & large (-.55) \\
\hline
\end{tabular}

Note. WTRG: $n=12$, PTRG: $n=12$, CG: $n=11$

The data on the whole, thus, seem to suggest that a recitation approach, either in a whole or partial manner, is likely to have a lasting effect on the learning of constructions. This observation itself may not quite be illuminative in light of the large amount of time the students in both groups spent on the recitation; however, these improvements were observed in a speaking test, any similar empirical evidence of which is very hard to find in the existing literature, and what was found here corroborates the effectiveness of text memorization for the learning of multi-word expressions.

FIGURE 1

MEAN DISTRIBUTION OF Z-SCORE FOR CONSTRUCTIONS USED FROM DIALOGS FOR 'DIRECT APPLICATION' PROMPTS

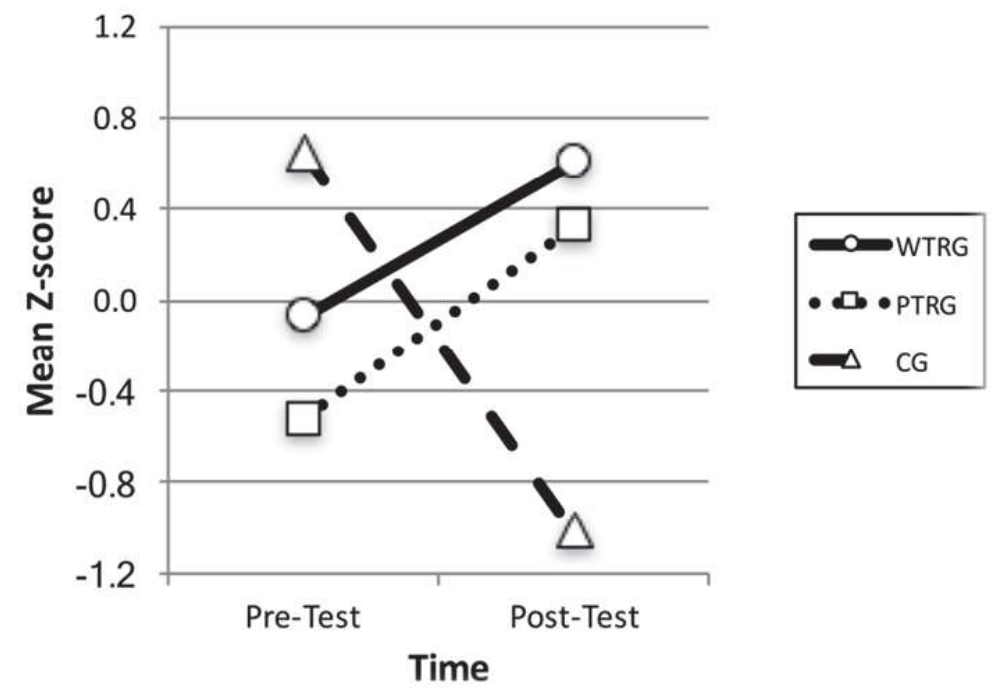




\section{FIGURE 2 \\ GROUP-BY-GROUP BOXPLOTS SHOWING IMPROVEMENT IN Z-SCORE FOR CONSTRUCTIONS USED FROM DIALOGS FOR 'DIRECT APPLICATION' PROMPTS}

Whole-text Recitation Group

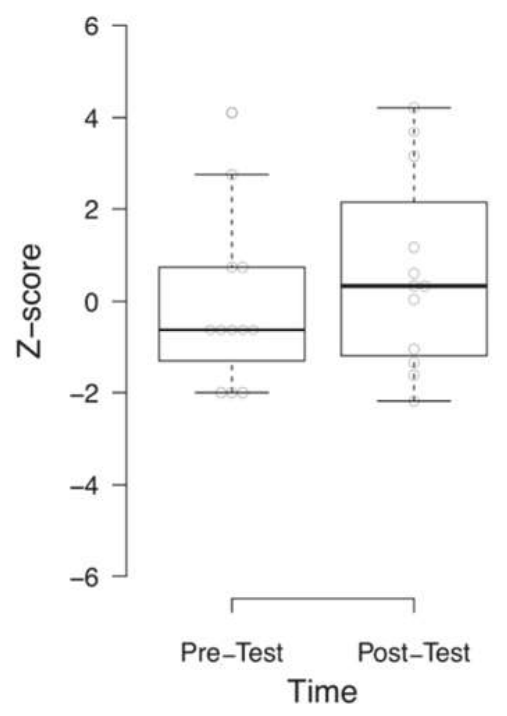

Partial-text Recitation Group

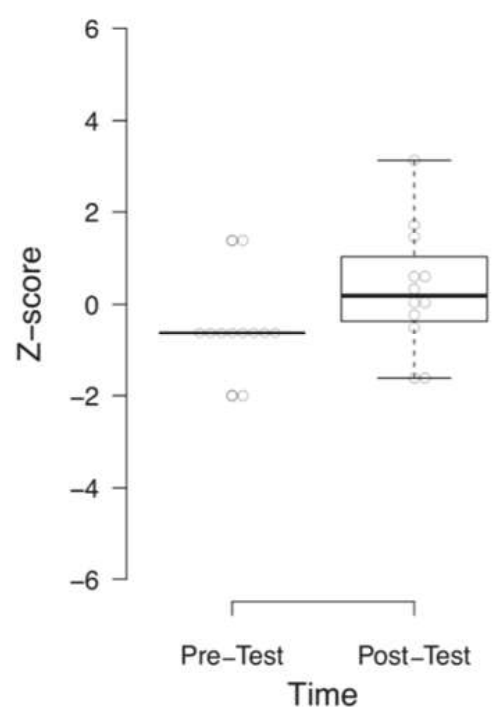

Contrast Group

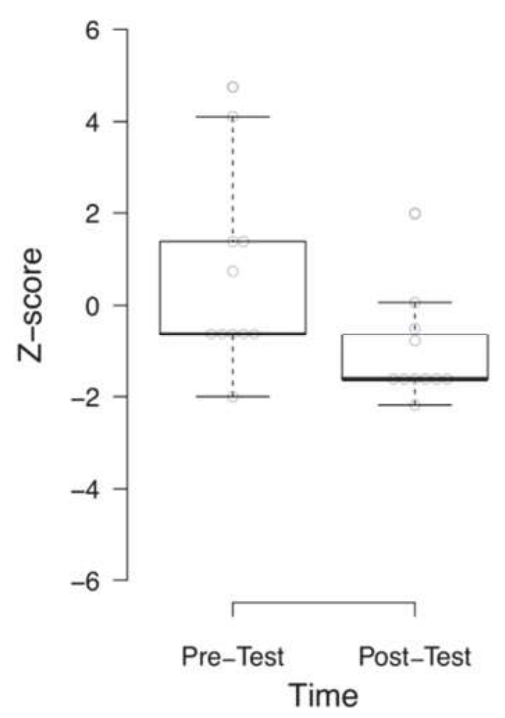

Although a significant improvement being detected only in the case of PTRG seems to suggest that partial-text recitation may work more effectively than whole-text recitation, at least with direct application prompts, there is an important argument for the WTR instruction having worked, in fact, better than the PTR instruction, an argument that finds support from a study by Peters (2012). Investigating the effect on retention of typographic enhancement and of glossing, a form of input enhancement, Peters found that the participants in the treatment group, who worked on texts with typographic enhancement (underlining and bold font) were better able to recollect glossed multi-word expressions from reading with the enhancement. One methodological issue with her study was that the students had been informed that a vocabulary post-test would follow, which means that they may have made more of an effort to remember the highlighted items in the text than those which were not highlighted. In the case of the study presented here, the administration of a post-test was announced beforehand, too. It is thus conceivable that some students in both WTRG and PTRG made an extra effort to remember the material. Assuming that they did make an extra effort to remember the material as a preparation for taking the Post-Test, then, PTRG had a better chance of obtaining good scores, because they would have thought that the focus of the test would be those words in the blanks that they had committed to memory, whereas WTRG would have had to determine for themselves where the focus of the test was going to be, because they were expected to memorize everything. Looking at this point from a different angle, it is possible that WTRG had indeed learned more linguistic items than PTRG because a great majority of the words and phrases that WTRG had memorized which PTRG had not were not in the Post-Test. After all, WTRG must have invested a far more amount of time on the recitation of the texts, so it is reasonable to imagine more learning having taken place for WTRG than PTRG. Thus, although PTRG performed better than WTRG on this part of the test, the learning outcome of WTRG should perhaps be considered to be greater. Of course, such an interpretation is not possible solely on the basis of the results found in this part of the speaking test; however, we will see below some further evidence that supports this argument when we analyze the data on the 'reading-aloud short sentences' part of the test.

Moving on to the discussion of the 'modified application' prompts, neither recitation group demonstrated noteworthy improvement, unlike the case with their performances on the 'direct application' prompts where both recitation approaches seemed promising, despite the fairly large amount 
of time invested on memorization by both recitation groups. Table 3 and Figures 3-4 display the z-score changes for constructions from the dialog material used for the 'modified application' prompts in this part of the test. Unlike the case of the 'direct application' prompts, no significant improvement was confirmed from any group (WTRG: $z=.706, p=.480, r=.15$ [small effect]; PTRG: $z=-.392, p=.695, r=-.08$ [almost no effect]; CG: $z=-1.689, p=.091, r=-.36$ [medium effect]). It thus appears that both types of recitation tasks help the learners to become able to use phrases in their original forms, but neither is of itself sufficient to help them apply these items in modified forms. The overall non-significant results for modified application prompts can be comparable to the findings of Nekrasova's study (2009), which indicates that 'fixed' formulaic expressions tend to be used by L2 learners more than 'non-fixed' ones. Presumably, it would take additional encounters in authentic texts and communication for learners to become able to make applications of phrases with slots to fill. Merely engaging learners in text memorization, whether with a whole-text or partial-text approach, is insufficient to drive the kinds of analysis at the time of encoding that will make the constructions therein available for flexible language use in the future.

TABLE 3

IMPROVEMENT IN Z-SCORE FOR CONSTRUCTIONS USED FROM DIALOGS FOR 'MODIFIED APPLICATION' PROMPTS

\begin{tabular}{|c|c|c|c|c|c|c|}
\hline \multirow{2}{*}{ Group } & \multicolumn{2}{|c|}{ Pre-test } & \multicolumn{2}{|c|}{ Post-test } & \multirow{2}{*}{$p$} & \multirow{2}{*}{$r$} \\
\hline & $M$ & $(S D)$ & $M$ & $(S D)$ & & \\
\hline WTRG & .01 & (1.69) & .88 & $(2.26)$ & .480 & small (.15) \\
\hline PTRG & .38 & (1.87) & .05 & (.99) & .695 & almost no (-.08) \\
\hline $\mathrm{CG}$ & -.42 & (1.51) & -1.01 & $(.97)$ & .091 & medium $(-.36)$ \\
\hline
\end{tabular}

\section{MEAN DISTRIBUTION OF Z-SCORE FOR CONSTRUCTIONS USED FROM DIALOGS FOR 'MODIFIED APPLICATION' PROMPTS}

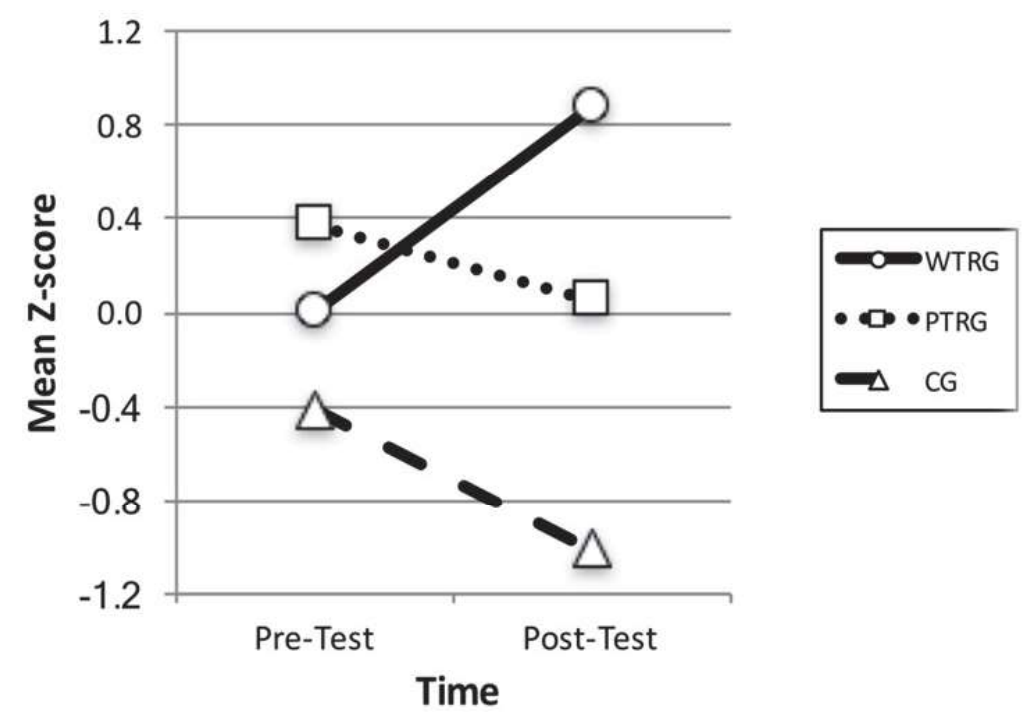




\section{FIGURE 4 \\ GROUP-BY-GROUP BOXPLOTS SHOWING IMPROVEMENT IN Z-SCORE FOR CONSTRUCTIONS USED FROM DIALOGS FOR 'MODIFIED APPLICATION' PROMPTS}

Whole-text Recitation Group

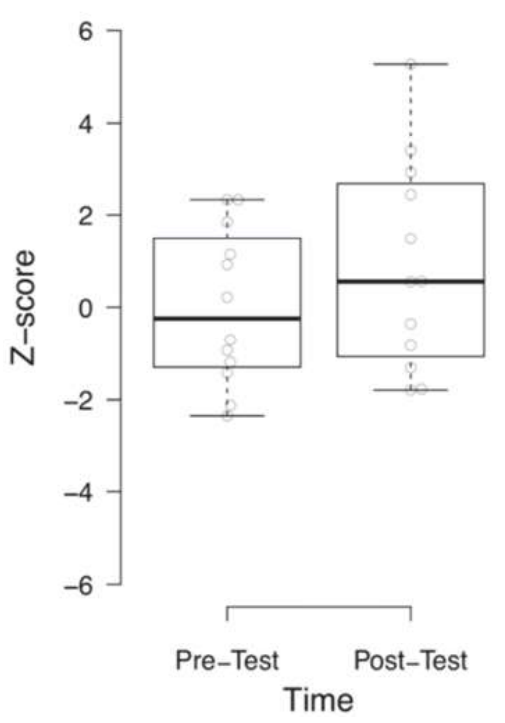

Partial-text Recitation Group

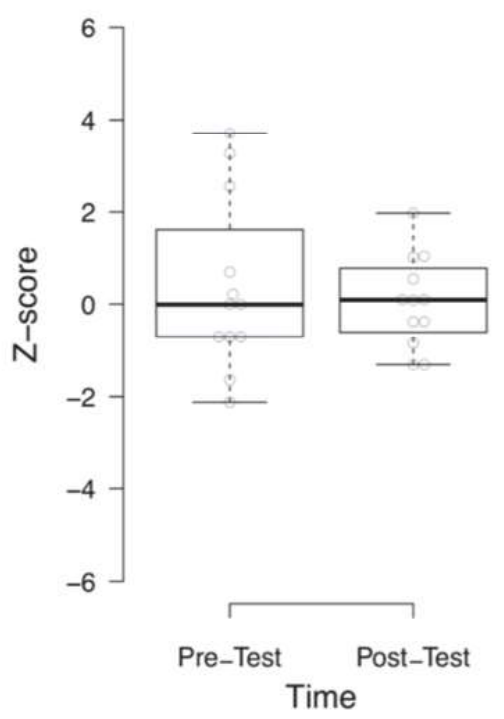

Contrast Group

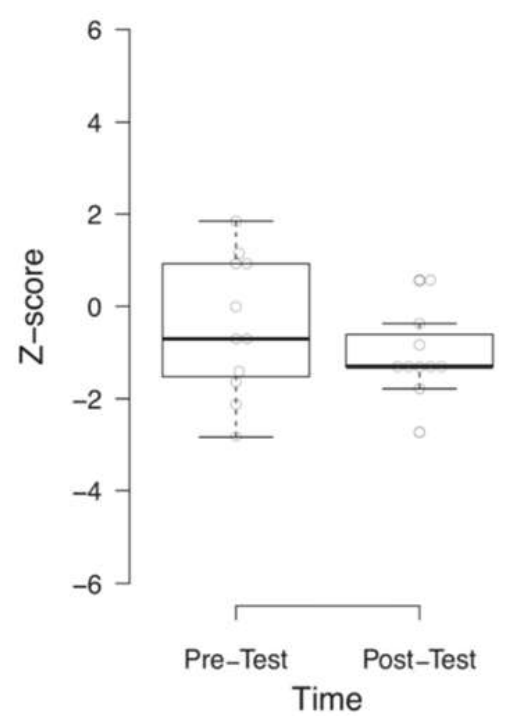

An additional observation from the students' $z$-score changes for both direct and modified application prompts is that a partial-text recitation approach might actually have a better chance of bringing about learning of language chunks across different types of learners than does a whole-text recitation approach. Looking closely at the score changes from the Pre- to Post-Test for both prompt types (Figure 5), WTRG's dispersion is greater, in both cases, than PTRG's. A reasonable explanation for this greater dispersion is that there may have been a mismatch between what is involved with whole-text recitation and the language learning styles or abilities of certain students in WTRG. That is, although those students presumably spent far more time on text memorization than PTRG did, they may not have gained as much as other high achievers in WTRG because they were either less good at retaining the studied material by way of rote memorization or less receptive to such an approach. Consequences of such a mismatch then may have been more manifest with WTRG than with PTRG simply because the former group was forced to grapple with a far larger amount of language. If this assumption turns out correct, it may be safer for classroom practitioners to adopt a partial-text recitation approach, since a whole-text recitation may not work well with particular types of learners. 
FIGURE 5

\section{GROUP-BY-GROUP BOXPLOTS SHOWING Z-SCORE CHANGES FROM PRE- TO POST- TEST FOR BOTH PROMPT TYPES}

\section{Direct Application}

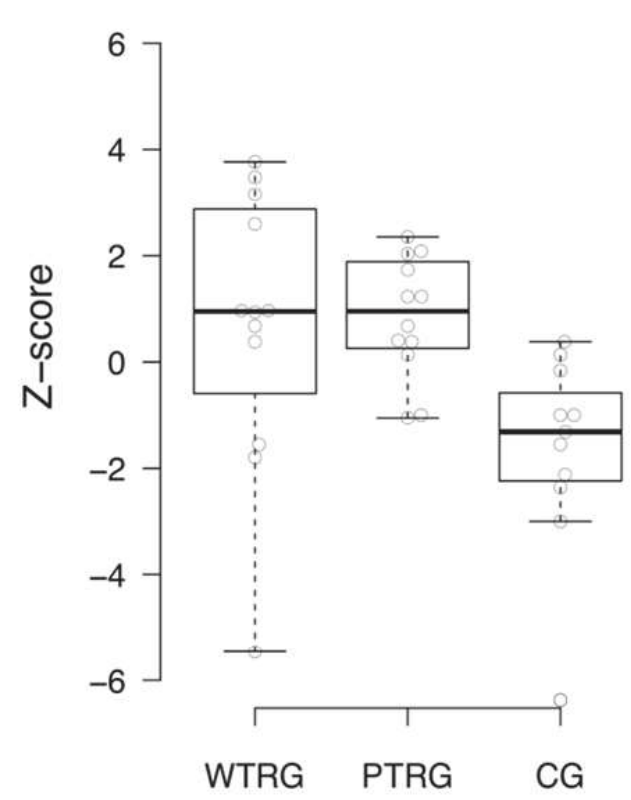

Modified Application

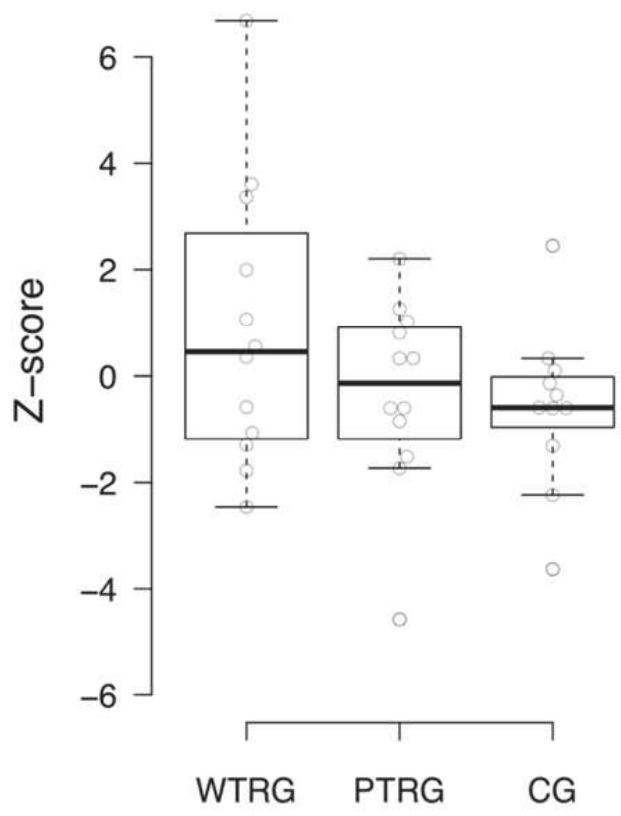

Finally, as a further consideration regarding the adoption of either whole-text or partial-text recitation, the three groups' performances on the 'reading-aloud short sentences' part of the test are a clear case where whole-text recitation does have an advantage in terms of learning effects over partial-text recitation, a fact which also should be taken into account when deciding on which approach to employ in a language class. Table 4 and Figures 6-7 present the changes in all three groups' scores for this part of the speaking test, with a significant improvement by WTRG and PTRG but not by CG (WTRG: $z=3.084, p$ $=.002^{* *}, r=.63$ [large effect]; PTRG: $z=2.223, p=.026^{*}, r=.45$ [medium effect]; CG: $z=1.294, p$ $=.196, r=.28$ [small effect]), and a Mann-Whitney test further run on the score increases made by these two groups found that WTRG's improvement was even significantly larger than PTRG's $(U=-3.324, p$ $<.000^{* *}, r=-.68$ [large effect]). These results show that both types of recitation tasks instigated learning on articulatory aspects of the constructions covered in the dialog material, and that whole-text memorization had even greater effect on this particular aspect than partial-text memorization. 
TABLE 4

IMPROVEMENT IN ARTICULATORY APPROPRIATENESS IN READING-ALOUD SHORT SENTENCES

\begin{tabular}{lcccccl}
\hline \multirow{2}{*}{ Group } & \multicolumn{2}{c}{ Pre-test } & \multicolumn{2}{c}{ Post-test } & \multirow{2}{*}{$p$} & \multicolumn{1}{c}{$r$} \\
\cline { 2 - 4 } & $M$ & $(S D)$ & $M$ & $(S D)$ & & \\
\hline WTRG & 3.25 & $(1.55)$ & 7.42 & $(1.00)$ & $.002^{* *}$ & large $(.63)$ \\
PTRG & 3.83 & $(1.75)$ & 5.17 & $(2.66)$ & $.026^{*}$ & medium $(.45)$ \\
CG & 4.55 & $(1.92)$ & 5.36 & $(1.57)$ & .196 & small $(.28)$ \\
\hline
\end{tabular}

FIGURE 6

MEAN DISTRIBUTION OF SCORES FOR ARTICULATORY APPROPRIATENESS IN READING-ALOUD SHORT SENTENCES

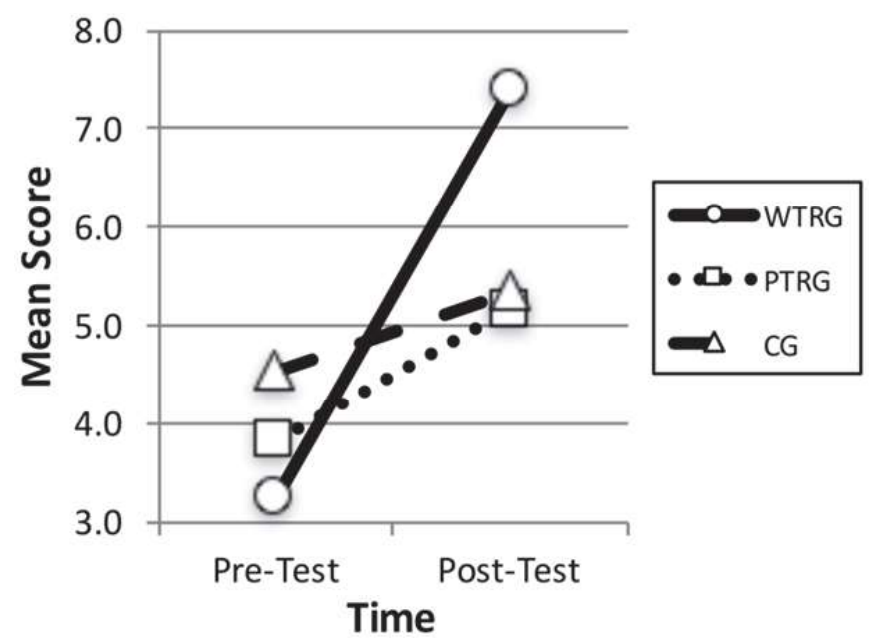

FIGURE 7

GROUP-BY-GROUP BOXPLOTS SHOWING IMPROVEMENT IN ARTICULATORY APPROPRIATENESS IN READING-ALOUD SHORT SENTENCES
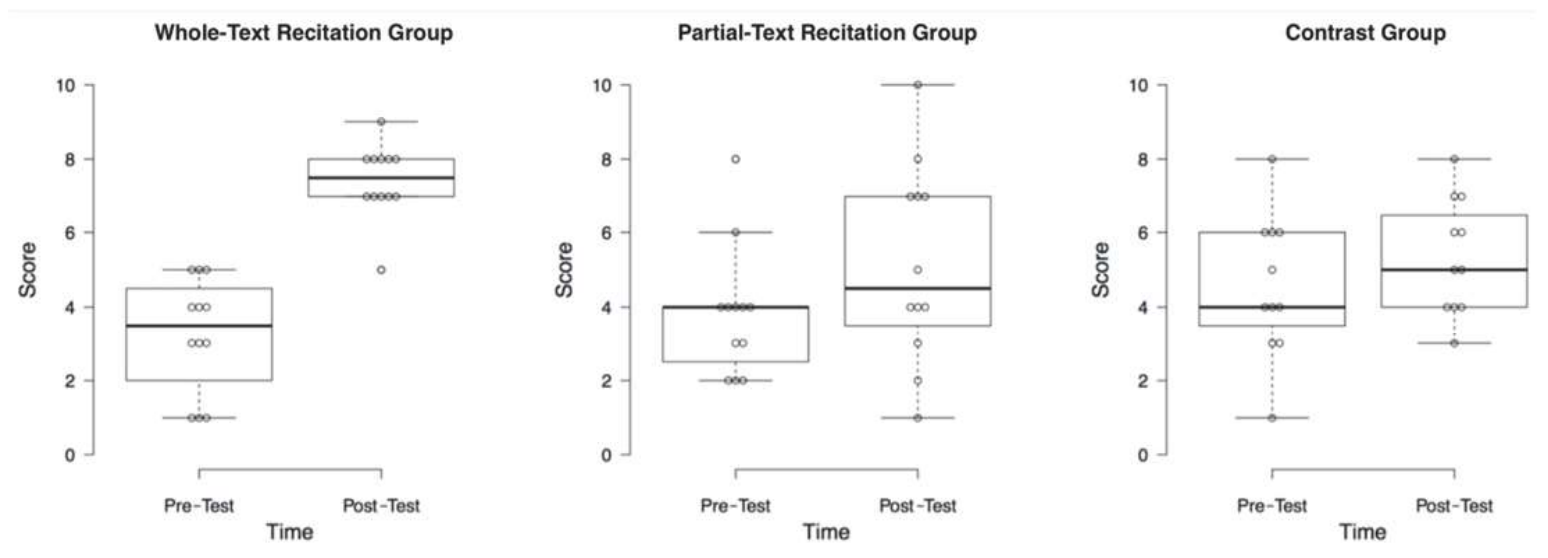


\section{CONCLUSIONS}

The following represents a summary of the results and interpretations. First, looking at the data as a whole, it can be concluded that whole- and partial-text recitation tasks utilizing materials prepared prior to instruction with the duration of an academic semester did bring about more learning of multi-word expressions. It can also be said that there is a significant variance in facilitative effects between the two types of task. If we look at the 'direct application' prompts alone, the test results indicate a slight advantage for partial-text memorization, although it can be argued that whole-text memorization might actually have been more effective. In the case of the 'modified application' prompts, neither recitation group showed more effective results than the CG. In terms of pronunciation, the speaking test results strongly suggest that whole-text recitation is more conducive to learning than partial-text recitation. As a whole, the results indicate that a whole-text memorization approach promotes more learning of phrases than a partial-text memorization approach, although the former is obviously more time-consuming and may also come with a higher chance of the approach not working effectively with learners whose learning abilities or styles do not match rote memorization.

There were some methodological issues with the present study's research design. One of those, already pointed out earlier, was the insufficient reliability estimates for the speaking test components. Another arguable limitation of this study is the validity of the speaking tests employed. While this study adds to the very small number of studies that utilize speaking tests to measure the participants' knowledge of particular constructions (in the case of this study, those contained in the dialogs), the specific designs of the tests, which were meant to measure certain aspects of the participants' knowledge of multi-word expressions, could no doubt be improved. Furthermore, the CG could have been a more comparable group if instruction of some kind about the dialog materials worked on by the two treatment groups had at least been given to this group as well.

In conclusion, it is hoped that the findings presented here can provide offer insights to teaching practitioners seeking optimal ways to deal with formulaic language in the classroom. The literature review in this paper pointed to the serious lack of research into the extent to which classroom teaching can promote formulaic learning by means of text memorization. It was also shown that the adoption of speaking measures as a way of testing constructions in memory and fluent language use has been even more scarce in the pertinent studies. This lack was one major motivation for the project reported on in this paper, and all methodological limitations taken into consideration, it is hoped that this study makes a contribution to the research into the effectiveness of utilizing text memorization, a still controversial area, to facilitate the acquisition of formulaic language.

\section{ACKNOWLEDGEMENTS}

I am very grateful to Joseph Heilman, Yutaka Iguchi, Kevin Mark, Masashi Negishi, Hideyuki Takashima, and Asako Yoshitomi, all of whom gave me substantial advice in the doctoral research stage of this project. I am also thankful to all of the participants and the anonymous reviewers.

\section{FUNDING}

This research was partly supported by MEXT/JSPS Grant-in-Aid for Young Scientists (B) 24720271 . 


\section{REFERENCES}

Anderson, A., \& Lynch, T. (1988). Listening. Oxford: Oxford University Press.

Boers, F., \& Lindstromberg, S. (2012). Experimental and intervention studies on formulaic sequences in a second language. Annual Review of Applied Linguistics, 32, 83-110. http://doi.org/10.1017/S0267190512000050

Dai, Z., \& Ding, Y. (2010). Effectiveness of text memorization in EFL learning of Chinese students. In D. Wood (Ed.), Perspectives on Formulaic Language: Acquisition and Communication (pp. 71-87). London: Continuum International Publishing Group.

Ellis, N. C. (1996). Sequencing in SLA: Phonological memory, chunking, and points of order. Studies in Second Language Acquisition, 18(01), 91-126. http://doi.org/10.1017/S0272263100014698

Ellis, N. C. (2002). Frequency effects in language processing: A review with implications for theories of implicit and explicit language acquisition. Studies in Second Language Acquisition, 24(02), 143188. http://doi.org/10.1017/S0272263102002024

Erman, B., \& Warren, B. (2000). The idiom principle and the open-choice principle. Text, 20, $29-62$.

Fitzpatrick, T., \& Wray, A. (2006). Breaking up is not so hard to do: Individual differences in L2 memorization. The Canadian Modern Language Review, 63(1), 35-56. http://doi.org/10.1353/cml.2006.0044

Millar, N. (2010). The processing of malformed formulaic language. Applied Linguistics, 32(2), 1-21. http://doi.org/10.1093/applin/amq035

Nekrasova, T. M. (2009). English L1 and L2 speakers' knowledge of lexical bundles. Language Learning, 59(3), 647-686. http://doi.org/10.1111/j.1467-9922.2009.00520.x

Pawley, A., \& Syder, F. H. (1983). Two puzzles for linguistic theory: Nativelike selection and nativelike fluency. In J. Richards \& R. Schmidt (Eds.), Language and Communication (pp. 191-225). London: Longman.

Peters, E. (2012). Learning German formulaic sequences: The effect of two attention-drawing techniques. The Language Learning Journal, 40(1), 65-79. http://doi.org/10.1080/09571736.2012.658224

Skehan, P. (1998). A Cognitive Approach to Language Learning. Oxford: Oxford University Press.

Stengers, H., Boers, F., Housen, A., \& Eyckmans, J. (2011). Formulaic sequences and L2 oral proficiency: Does the type of target language influence the association? IRAL, 49(4), 321-343.

Wray, A. (2004). "Here's one I prepared earlier": Formulaic language learning on television. In N. Schmitt (Ed.), Formulaic Sequences: Acquisition, Processing, and Use (pp. 249-268). Amsterdam: John Benjamins Publishing Company.

Wray, A., \& Fitzpatrick, T. (2008). Why can't you just leave it alone? Deviations from memorized language as a gauge of nativelike competence. In F. Meunier \& S. Granger (Eds.), Phraseology in Foreign Language Learning and Teaching (pp. 123-147). Amsterdam: John Benjamins Publishing Company.

Wray, A., \& Fitzpatrick, T. (2010). Pushing learners to the extreme: the artificial use of prefabricated material in conversation. Innovation in Language Learning and Teaching, 4(1), 37-51. http://doi.org/10.1080/17501220802596413

Wray, A., \& Perkins, M. R. (2000). The functions of formulaic language: An integrated model. Language \& Communication, 20(1), 1-28. http://doi.org/10.1016/S0271-5309(99)00015-4

$\mathrm{Yu}, \mathrm{X}$. (2009). A formal criterion for identifying lexical phrases: Implication from a classroom experiment. System, 37(4), 689-699. http://doi.org/10.1016/j.system.2009.09.012 


\section{APPENDIX A \\ A SUMMARY OF ALL PROMPTS IN 'READING-ALOUD SHORT SENTENCES’AND NOTES}

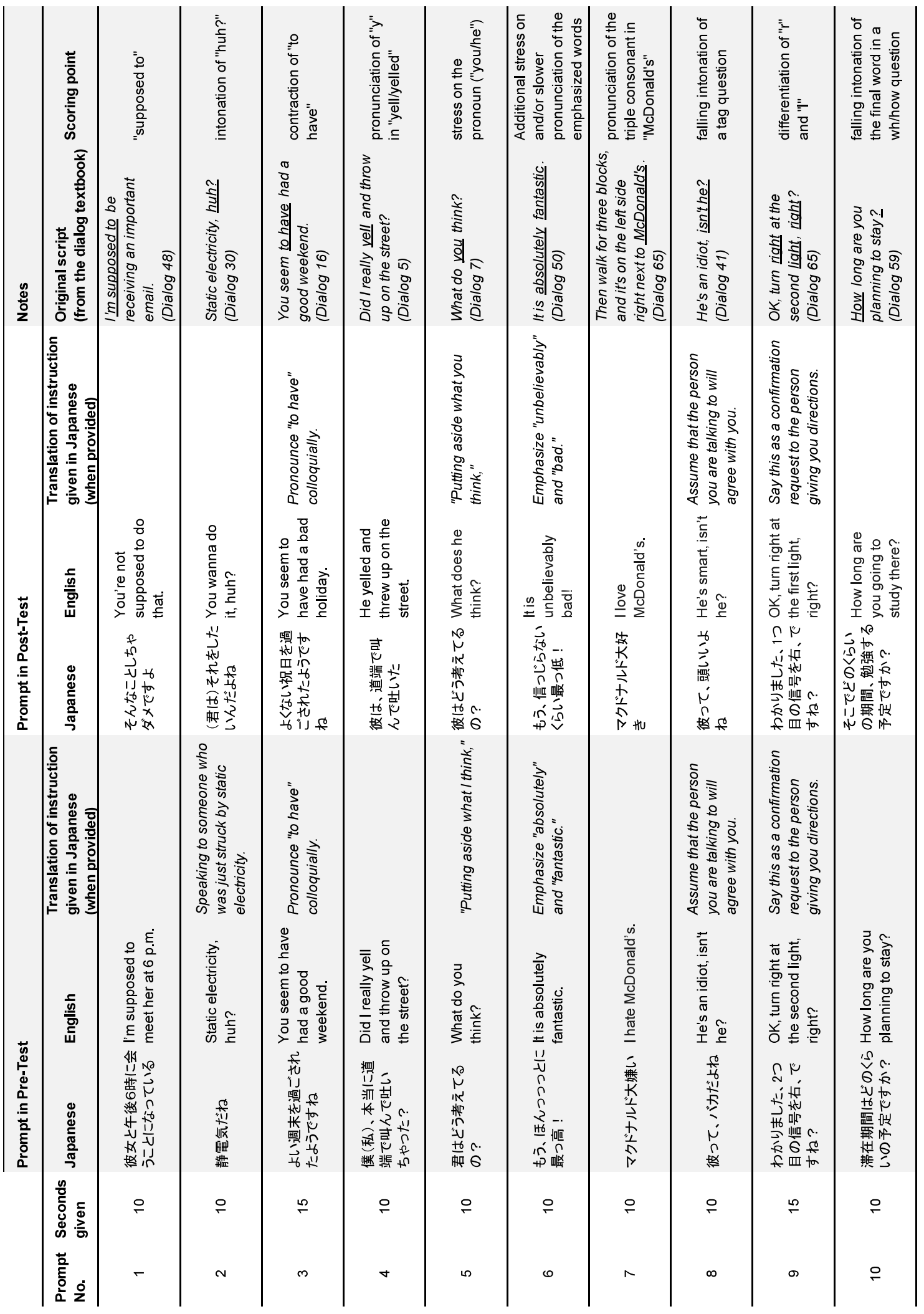




\section{APPENDIX B \\ A SUMMARY OF THE PROMPTS IN 'RESPONDING READILY'AND SCORING CRITERIA}

\begin{tabular}{|c|c|c|c|c|}
\hline & Original prompt & $\begin{array}{l}\text { Target sentence(s) in the } \\
\text { dialog textbook }\end{array}$ & $\begin{array}{l}\text { Sample modified } \\
\text { expression using } \\
\text { FSs from the } \\
\text { dialog textbook }\end{array}$ & $\begin{array}{l}\text { Lexical phrases } \\
\text { counted for } \\
\text { scoring }\end{array}$ \\
\hline \multirow[t]{4}{*}{$\begin{array}{l}\text { Repeated } \\
\text { direct } \\
\text { application } \\
\text { prompts }\end{array}$} & $\begin{array}{l}\text { ある教員に対して、(あなたの) 小論 } \\
\text { 文の提出の期限延長が可能かどう } \\
\text { か探りを入れてみてください。 }\end{array}$ & $\begin{array}{l}\text { I was wondering if you } \\
\text { could give me an } \\
\text { extension for handing in } \\
\text { my essay. } \\
\text { (Dialog 11) }\end{array}$ & $\begin{array}{l}\text { (no need for } \\
\text { modification) }\end{array}$ & $\begin{array}{l}\text { 1) I was } \\
\text { wondering if...; 2) } \\
\text { you could; } 3 \text { ) give } \\
\text { me; } 4 \text { ) an } \\
\text { extension for; 5) } \\
\text { handing in }\end{array}$ \\
\hline & $\begin{array}{l}\text { 「世の中そんなものだ」と、ある意 } \\
\text { 味、諦めまじりの気持ちを表現してく } \\
\text { ださい。 }\end{array}$ & $\begin{array}{l}\text { That's the way it goes. } \\
\text { (Dialog 17) }\end{array}$ & $\begin{array}{l}\text { (no need for } \\
\text { modification) }\end{array}$ & $\begin{array}{l}\text { That's the way it } \\
\text { goes. }\end{array}$ \\
\hline & $\begin{array}{l}\text { あなたは友人からある誘いを受けま } \\
\text { した。遠慮する旨、回答してくださ } \\
\text { い。 }\end{array}$ & $\begin{array}{l}\text { I'll pass. } \\
\text { (Dialog 28) }\end{array}$ & $\begin{array}{l}\text { (no need for } \\
\text { modification) }\end{array}$ & I'll pass \\
\hline & $\begin{array}{l}\text { 友人に向かって「昼までにこの(自分 } \\
\text { の)PCで(この)レポートを仕上げな } \\
\text { いといけないんだよね」と言ってくだ } \\
\text { さい。 }\end{array}$ & $\begin{array}{l}\text { l've gotta finish up this } \\
\text { report on my computer by } \\
\text { noon. } \\
\text { (Dialog 48) }\end{array}$ & $\begin{array}{l}\text { (no need for } \\
\text { modification) }\end{array}$ & $\begin{array}{l}\text { 1) (have) gotta; } 2 \text { ) } \\
\text { finish UP; 3) on...; } \\
\text { 4) by... }\end{array}$ \\
\hline \multirow[t]{4}{*}{$\begin{array}{l}\text { Repeated } \\
\text { modified } \\
\text { application } \\
\text { prompts }\end{array}$} & $\begin{array}{l}\text { 「中国がアメリカに次いで世界第2位 } \\
\text { の経済(大国)になったことをどう思 } \\
\text { う？」と友人に尋ねてください。 } \\
\end{array}$ & $\begin{array}{l}\text { Uh, what do you think of } \\
\text { Japan becoming the third } \\
\text { world, uh, third biggest } \\
\text { world economy after } \\
\text { China? } \\
\text { (Dialog 7) }\end{array}$ & $\begin{array}{l}\text { What do you think } \\
\text { of China } \\
\text { becoming the } \\
\text { second biggest } \\
\text { world economy } \\
\text { after the US? }\end{array}$ & $\begin{array}{l}\text { 1) What do you } \\
\text { think; } 2 \text { ) think of; } \\
\text { 3) Prep. + Noun + } \\
\text { Gerund; 4) second } \\
\text { + Superlative; 5) } \\
\text { after... }\end{array}$ \\
\hline & $\begin{array}{l}\text { あなたの家庭は裕福ではありませ } \\
\text { ん。「うちがもし裕福だったら学費を } \\
\text { 払う心配をしなくて済むのになあ」と } \\
\text { 表現してください。 }\end{array}$ & $\begin{array}{l}\text { What would you do if you } \\
\text { won the lottery? / You } \\
\text { wouldn't have to worry } \\
\text { about paying your rent } \\
\text { then. } \\
\text { (Dialog 19) }\end{array}$ & $\begin{array}{l}\text { If our family was } \\
\text { wealthy, I would } \\
\text { not have to worry } \\
\text { about paying the } \\
\text { tuition to the } \\
\text { school. }\end{array}$ & $\begin{array}{l}\text { 1) Subjunctive; } 2 \text { ) } \\
\text { wouldn't have to; } \\
\text { 3) I wish (cf. from } \\
\text { another dialog) }\end{array}$ \\
\hline & $\begin{array}{l}\text { あなたは、友人が見たいと言った映 } \\
\text { 画をDVDレンタルてきました。しか } \\
\text { し友人は見たくないと言います。その } \\
\text { 友人に向かって、「見たくないってど } \\
\text { ういうことよ? 見たいって言ったじゃ } \\
\text { ん！」と文句を言ってください。 }\end{array}$ & $\begin{array}{l}\text { What, what do you mean } \\
\text { you've decided not to go? } \\
\text { (Dialog 32) }\end{array}$ & $\begin{array}{l}\text { What do you } \\
\text { mean you don't } \\
\text { wanna see this } \\
\text { movie. You said } \\
\text { you wanted to see } \\
\text { it. }\end{array}$ & $\begin{array}{l}\text { 1) What do you } \\
\text { mean; } 2 \text { ) What do } \\
\text { you mean "..."?; 3) } \\
\text { Sequence of } \\
\text { tenses (cf. from } \\
\text { another dialog) } \\
\end{array}$ \\
\hline & $\begin{array}{l}\text { 友人に向かって「頼りにしているよ」 } \\
\text { と言ってください。 }\end{array}$ & $\begin{array}{l}\text { You can count on it. } \\
\text { (Dialog } 36)\end{array}$ & $\begin{array}{l}\text { I'm counting on } \\
\text { you. }\end{array}$ & 1) count on \\
\hline
\end{tabular}




\section{APPENDIX B (CONTINUED)}

\begin{tabular}{|c|c|c|c|c|}
\hline & Original prompt & $\begin{array}{l}\text { Target sentence(s) in the } \\
\text { dialog textbook }\end{array}$ & $\begin{array}{l}\text { Sample modified } \\
\text { expression using } \\
\text { FSs from the } \\
\text { dialog textbook }\end{array}$ & $\begin{array}{l}\text { Lexical phrases } \\
\text { counted for } \\
\text { scoring }\end{array}$ \\
\hline \multirow{4}{*}{$\begin{array}{l}\text { Non-repeated } \\
\text { direct } \\
\text { application } \\
\text { prompts } \\
\text { in Pre-Test }\end{array}$} & $\begin{array}{l}\text { 友人とふたりで何かを決断しなけれ } \\
\text { ばなりません。「君に任せるよ」と } \\
\text { 言ってください。 }\end{array}$ & $\begin{array}{l}\text { I'll leave it to you. } \\
\text { (Dialog 35) }\end{array}$ & $\begin{array}{l}\text { (no need for } \\
\text { modification) }\end{array}$ & I'll leave it to you \\
\hline & $\begin{array}{l}\text { 「念には念を(用心に越したことはな } \\
\text { い:転ばぬ先の杖)」の意を表現して } \\
\text { ください。 }\end{array}$ & $\begin{array}{l}\text { Better safe than sorry. } \\
\text { (Dialog 39) }\end{array}$ & $\begin{array}{l}\text { (no need for } \\
\text { modification) }\end{array}$ & $\begin{array}{l}\text { better safe than } \\
\text { sorry }\end{array}$ \\
\hline & $\begin{array}{l}\text { 友人に向かって、「(あなたに)同情 } \\
\text { できません。(あなたの)自業自得で } \\
\text { す」と言ってください。 }\end{array}$ & $\begin{array}{l}\text { I can't feel sorry for you. It's } \\
\text { your fault. } \\
\text { (Dialog 45) }\end{array}$ & $\begin{array}{l}\text { (no need for } \\
\text { modification) }\end{array}$ & $\begin{array}{l}\text { 1) can't feel sorry } \\
\text { for you; 2) it's your } \\
\text { fault }\end{array}$ \\
\hline & $\begin{array}{l}\text { あなたは友人から、ある実現の難し } \\
\text { い頼みごとをされました。(実際に } \\
\text { は何もできないかもしれないが) 何と } \\
\text { か手を打つようにします」と回答して } \\
\text { ください。 }\end{array}$ & $\begin{array}{l}\text { I'll see what I can do. } \\
\text { (Dialog 66) }\end{array}$ & $\begin{array}{l}\text { (no need for } \\
\text { modification) }\end{array}$ & $\begin{array}{l}\text { 1) I'll see; 2) what I } \\
\text { can do }\end{array}$ \\
\hline \multirow{4}{*}{$\begin{array}{l}\text { Non-repeated } \\
\text { direct } \\
\text { application } \\
\text { prompts } \\
\text { in Post-Test }\end{array}$} & $\begin{array}{l}\text { ある目上の人に、少し話させてもら } \\
\text { えないか尋ねてください。 }\end{array}$ & $\begin{array}{l}\text { Could I speak to you for a } \\
\text { moment? } \\
\text { (Dialog 11) }\end{array}$ & $\begin{array}{l}\text { (no need for } \\
\text { modification) }\end{array}$ & $\begin{array}{l}\text { 1) Could l; 2) for a } \\
\text { moment; 3) a little } \\
\text { (cf. from another } \\
\text { dialog) }\end{array}$ \\
\hline & $\begin{array}{l}\text { あなたは自宅でパーティを開きま } \\
\text { す。ある友人が、来てもよいかどうか } \\
\text { 迷っています。その人に、「人数は多 } \\
\text { い方が楽しくなるから」と後押ししてく } \\
\text { ださい。 }\end{array}$ & $\begin{array}{l}\text { The more, the merrier. } \\
\text { (Dialog 31) }\end{array}$ & $\begin{array}{l}\text { (no need for } \\
\text { modification) }\end{array}$ & $\begin{array}{l}\text { The + } \\
\text { Comparative..., } \\
\text { the + Comparative } \\
\ldots\end{array}$ \\
\hline & $\begin{array}{l}\text { 「それはおかしい(理にかなっていな } \\
\text { い)」と言ってください。 }\end{array}$ & $\begin{array}{l}\text { It doesn't make sense. } \\
\text { (Dialog 46) }\end{array}$ & $\begin{array}{l}\text { (no need for } \\
\text { modification) }\end{array}$ & make sense \\
\hline & $\begin{array}{l}\text { あなたの忠告を聞かなかった友人 } \\
\text { が、そのために失敗をしました。その } \\
\text { 友人に向かって、「ほら、だから言っ } \\
\text { たでしょ」と言ってくたさい。 }\end{array}$ & $\begin{array}{l}\text { See? I told you. } \\
\text { (Dialog 53) }\end{array}$ & $\begin{array}{l}\text { (no need for } \\
\text { modification) }\end{array}$ & $\begin{array}{l}\text { 1) See?; 2) told } \\
\text { you }\end{array}$ \\
\hline
\end{tabular}




\section{APPENDIX B (CONTINUED)}

\begin{tabular}{|c|c|c|c|c|}
\hline & Original prompt & $\begin{array}{l}\text { Target sentence(s) in the } \\
\text { dialog textbook }\end{array}$ & $\begin{array}{l}\text { Sample modified } \\
\text { expression using } \\
\text { FSs from the } \\
\text { dialog textbook }\end{array}$ & $\begin{array}{l}\text { Lexical phrases } \\
\text { counted for } \\
\text { scoring }\end{array}$ \\
\hline \multirow{4}{*}{$\begin{array}{l}\text { Non-repeated } \\
\text { modified } \\
\text { application } \\
\text { prompts } \\
\text { in Pre-Test }\end{array}$} & $\begin{array}{l}\text { 松崎に対して、結婚期間(結婚して } \\
\text { どれくらい経つのか)を尋ねてくださ } \\
\text { い。 }\end{array}$ & $\begin{array}{l}\text { How long have they been } \\
\text { going out together? } \\
\text { (Dialog 25) }\end{array}$ & $\begin{array}{l}\text { How long have } \\
\text { you been } \\
\text { married? }\end{array}$ & $\begin{array}{l}\text { 1) how long; } 2 \text { ) } \\
\text { have you; } 3 \text { ) been } \\
\text {.. }\end{array}$ \\
\hline & $\begin{array}{l}\text { 友人に向かって、「(自分は、)映画 } \\
\text { 館で最後に映画を観てからずいぶ } \\
\text { ん経ちます」と言ってください。 }\end{array}$ & $\begin{array}{l}\text {...and, uh, it's been a while } \\
\text { since l last saw his movie } \\
\text { at the theater. } \\
\text { (Dialog 31) }\end{array}$ & $\begin{array}{l}\text { It's been a while } \\
\text { since I last saw a } \\
\text { movie at the } \\
\text { theater. }\end{array}$ & $\begin{array}{l}\text { 1) It's been a } \\
\text { while; } 2 \text { ) since I } \\
\text { last; } 3 \text { ) at the } \\
\text { theater }\end{array}$ \\
\hline & $\begin{array}{l}\text { 「彼女にはうんざりだ」と言ってくださ } \\
\text { い。 }\end{array}$ & $\begin{array}{l}\text { I am sick of Pete! } \\
\text { (Dialog } 40)\end{array}$ & I'm sick of her. & $\begin{array}{l}\text { 1) sick of; } 2 \text { ) can't } \\
\text { stand (cf. from } \\
\text { another dialog) }\end{array}$ \\
\hline & $\begin{array}{l}\text { 「人の悪口は我慢出来ない」と言っ } \\
\text { てください。 }\end{array}$ & $\begin{array}{l}\text { I couldn't stand their bad- } \\
\text { mouthing. } \\
\text { (Dialog 43) }\end{array}$ & $\begin{array}{l}\text { I can't stand } \\
\text { badmouthing. }\end{array}$ & $\begin{array}{l}\text { 1) can't stand; 2) } \\
\text { badmouthing }\end{array}$ \\
\hline \multirow[t]{4}{*}{$\begin{array}{l}\text { Non-repeated } \\
\text { modified } \\
\text { application } \\
\text { prompts } \\
\text { in Post-Test }\end{array}$} & $\begin{array}{l}\text { 知人とレストランでタ食を済ませたし } \\
\text { 払いの場面です。相手に向かって、 } \\
\text { 「割り勘はまた今度で。今日は僕 } \\
\text { (私)に払わせてください」と言ってく } \\
\text { ださい。 }\end{array}$ & $\begin{array}{l}\text { It's on me. / Let me pay. I } \\
\text { OK, then, let's split the bill. } \\
\text { (Dialog 3) }\end{array}$ & $\begin{array}{l}\text { We'll split the bill } \\
\text { next time. For } \\
\text { today, let me pay. }\end{array}$ & $\begin{array}{l}\text { 1) on me; } 2 \text { ) let me } \\
\text { pay; } 3 \text { ) split the } \\
\text { bill; 4) l'll pay (cf. } \\
\text { from another } \\
\text { dialod }\end{array}$ \\
\hline & $\begin{array}{l}\text { 旅先でのことです。あなたの所持金 } \\
\text { が切れそうで焦っている感じを表現 } \\
\text { してください。 }\end{array}$ & $\begin{array}{l}\text {...I'm running out of ideas } \\
\text { here! } \\
\text { (Dialog 23) }\end{array}$ & $\begin{array}{l}\text { I'm running out of } \\
\text { cash! }\end{array}$ & $\begin{array}{l}\text { 1) Present } \\
\text { Progressive; } 2 \text { ) } \\
\text { run out of... }\end{array}$ \\
\hline & $\begin{array}{l}\text { あなたと友人が話しています。そこ } \\
\text { に知り合いの女性がやってきまし } \\
\text { た。「(彼女)とても幸せそう(嬉しそ } \\
\text { う)ですね。何か良いこと(知らせ)が } \\
\text { あったんでしょうね」と言ってくださ } \\
\text { い。 }\end{array}$ & $\begin{array}{l}\text { You look happy. You got } \\
\text { some good news, right? } \\
\text { (Dialog 51) }\end{array}$ & $\begin{array}{l}\text { She looks so } \\
\text { happy. She must' } \\
\text { ve got some good } \\
\text { news. }\end{array}$ & $\begin{array}{l}\text { 1) look...;2) } \\
\text { get/have good } \\
\text { news; } 3 \text { ) some } \\
\text { (news); 4) } \\
\text { something... } \\
\text { happen (cf. from } \\
\text { another dialog) } \\
\end{array}$ \\
\hline & $\begin{array}{l}\text { 通りを歩いていたら見知らぬ人から } \\
\text { 最寄りのATMがどこにあるか尋ねら } \\
\text { れました。(この通りを)3ブロック下 } \\
\text { り、右に曲がり、その左手にあるコン } \\
\text { ビニの中にある」と回答してください。 }\end{array}$ & $\begin{array}{l}\text { First, go straight to the } \\
\text { second light, and turn right. } \\
\text { / Then walk for three } \\
\text { blocks, and it's on the left } \\
\text { side right next to } \\
\text { McDonald's. } \\
\text { (Dialog 65) }\end{array}$ & $\begin{array}{l}\text { Go down this } \\
\text { street for three } \\
\text { blocks, turn right, } \\
\text { and the ATM is in } \\
\text { the convenience } \\
\text { store on the left. }\end{array}$ & $\begin{array}{l}\text { 1) go } \\
\text { (straight/down); 2) } \\
\text { for (three blocks); } \\
\text { 3) turn right; 4) on } \\
\text { the left }\end{array}$ \\
\hline
\end{tabular}

